\title{
REGENERATION OF OLD CITY CENTER CASE STUDY OLD BAZAR IN ZAKHO CITY CENTER, KURDISTAN REGION- IRAQ
}

\author{
Dr. Layla M. Raswol ${ }^{*}$ and Jowan B. Khorsheed ${ }^{* *}$ \\ ${ }^{* *}$ College Of Engineering, University of Duhok, Kurdistan Region-Iraq \\ *, College Of Engineering, University of Nawroz, Kurdistan Region-Iraq
}

\begin{abstract}
Zakho is one of the oldest towns in Iraqi Kurdistan Region. It is distinguished for its rich and diverse Architectural heritage. It has many cultural and historical sites and a city center that date back to the ancient time. The rapid urban development of the inner city has changed the historical character of the Old city with its cultural value. The additional new buildings have transformed the historical city area without any respect to its traditional structure and surrounding landscape. The main objectives of the research are protecting the architectural heritage and its historic value to bring life to Zakho old bazar as a case study, and regenerate the physical - and socio-economic environment through attractive mix use activities and public space.

This research will firstly identify and analyze the existing heritage components in old Zakho Bazar, which require protection and development in different aspects. It will highlight the challenges facing the built-up area and the decline of the historic places. Furthermore, it will explain the importance of adopting the regenerating concept to balance between the dynamic urban development and the architectural conservation of historical and cultural heritage as well as improving the infrastructure and the built environment.
\end{abstract}

KEY WORDS: Urban regeneration, Architectural heritage, Case study, Historic city center, Old bazar Zakho

\section{INTRODUCTION}

$\mathbf{T}$ The Old City Center of Zakho has experienced significant transformation in the last decades. During the past political and economic conditions, Old city area declined in economic, physical as well as social terms. The new urban development process has been taken place in the commercial and residential area with significant consequence for the social and physical environment of the old city characteristics. By defining urban regeneration concept the paper will identify the condition for regeneration in Old city center of Zakho and relevant approach for enhancing the living environment there. In addition, it will study the effect of new building environment on the historical characteristic of the area and present their consequences for urban function, landscape and people. The main research question is how to create a balance between the new development in the old urban fabric to keep the historic identity and the townscape of the city. The concept of Urban Regeneration

Urban regeneration is "a comprehensive and integrated vision and action which leads to resolution of urban problems and which seeks to bring about a lasting improvement in the economic, physical, social and environmental condition of an area" (Roberts, et al. 2000). The term of urban regeneration and urban revitalization are often used in the literature alternatively. (Couch et al., 2003) described urban regeneration as a field of public policy refers to the redevelopment of economic activity, restoration of environmental quality and recovery of social inclusion. (Gunay, 2008) argues that Urban conservation and revitalization represent general idea of urban regeneration, which is being interpreted as a process of revitalization and integration of the entities having historical, cultural and architectural values with certain economic and functional potential. The aim of urban revitalization is to put new life in cities and to upgrade areas for higher social and economic uses. (Bearegard \& Holcomb 1881). "Urban Regeneration moves beyond the aims, aspirations, and achievements of urban renewal, which is seen as a process of essentially physical change, urban development (or redevelopment), with its general mission and less well-defined purpose, and urban revitalization (or rehabilitation) which whilst suggests the need for action, fails to specify a precise method of approach" (Couch C,.1880). Many Factors such as location, regional economic condition, land use patterns, building form administrative structures, tools and mechanisms of 
interventions are important to shape the urban regeneration policy (Couch et al., 2003).

\section{The Background of Urban Regeneration}

Until the 1840s few countries in the world appreciate the value of their old cities. In Europe, conservation was limited to a concern for historical building of special importance, usually castle, palaces, churches, museum and other significant public building (Steinberg F., 1886). The idea of urban rehabilitation began during the post war era world war, when most Europe historic cities were destroyed. Between 1850s and 1870 s urban renewal were typically planned under massive government subsidies to revitalize deprived urban area and improve social and living condition in cities of North America and Western Europe. In 1880s Europe, urban policies have been started to encourage private Sector investment (Temelova.J, 2008). There was a need to recreate the physical components of environment in order to bring about regeneration and stimulate economic development of distressed inner city (Loftman \& Nevin, 1885; Smyth, 1884). Large numbers of cities around the world are developing strategies for urban regeneration and gentrification of the city historical centers based on creativity and innovation. Some of the most known contemporary urban regenerations are considered, among others, Hafen City in Hamburg, Potzdamer Platz in Berlin, Olympic infrastructure in Barcelona and Sidney, special interventions in Athens etc.(Michailidis T., Zaire D.T, 2011)

\section{Principle of urban Regeneration}

It is generally recognized that the best method to conserve the historical part of the city is to keep it in active use. It means to put new life into an area socially and economically by using its historical identity which is the unique characters that cannot be replaced, that should be protected and conserved. It is very important to find solution and planning strategies that can be adapted to the new use without damaging its character and special value. There are two approaches for urban regeneration: first, people based approaches aim at improve the living condition of the residents (e.g. New employment opportunities) and second, place based approaches which emphasize local economic development (e.g. Adaptive reuse and upgrading) (Zielenbach, 2000). The improvement of the physical structure and functional use of space create new urban landscape and enhance the local economic by opening new public spaces and modern life activities.

\section{Objectives and Goals of Urban Regeneration}

Urban regeneration process deals with actions leading to improving the physical structures of the Old city (modernization, revalorization) combined with the improvement of economic and social situation of the community. (Lorens, 2004) identifies different goals and objectives of urban regeneration process can be defined:

- Architectural, associated with physical renovation of the distressed structures, both buildings and public infrastructure,

- Technical, associated with upgrading the technical state of the urban infrastructure, includes roads and sewerage,

- Social and Economic ones, associated with economic revival of the declined areas and restructuring of the society along with providing better chances for social groups that are for this or that reason excluded from the regular life;

- environmental, as bad environmental situation is in many cases the major problem in distressed urban areas.

Urban regeneration programs help in providing modern technical solutions to the problems of environmental pollution of different sort. (Lorens, 2004)

\section{Research Objectives}

The historic city center represents a unique historical links with the past, a physical manifestation of the social and cultural tradition which has been developed to give the modern city and society its meaning and character (Steinberg.F, 1886). The main objective of this research is to enhance the economic development and city livability by preserving urban heritage in the old city center. The research will define old city center of Zakho as a place of potential rather of decay. There are many empty and abandoned building at the city center that can be temporary reused as a way to bring life to the area and transform it to attractive space for community.

\section{Research methodology}

To achieve research objectives qualitative data collection method is used. Two instruments of data collection are used visual study techniques and context analysis. The Old bazaar of Zakho is chosen as a case study as an important part of the city historic center. Through visiting the study area the existing condition and the main heritage components of the historic center in Zakho are 
identified and analyzed. The context analysis includes studying and analyzing the obtained data, maps and documents from Zakho Municipality, directory of archaeology and the available literature about the study area to determine the physical development, building condition and the recent changes of the traditional spatial structure. The existing heritage components in old Zakho Bazar, which require protection and development in different aspects, are highlighted to apply the regeneration concept. The gained information is transferred to GIS maps to show the finding and results of the study.

\section{Study area}

Zakho is a city in Duhok Governorate of Iraqi Kurdistan. The city is situated around $52 \mathrm{~km}$ northwest of Duhok city and around $57 \mathrm{~km}$ southeast of Cizre city in Turkey. Zakho is one of the oldest towns in the Kurdistan Region and has some historic landmarks and building to offer. The city has been recognized during history as a living center for different cultures and religions. Both Christians and Jews were living in Zakho. Zakho was formerly known for its synagogues and large Jewish community and was known as "The Jerusalem of Assyria" Figure(1) (Duhok Municipalities Directory, 2011). The historic core of Zakho is situated on an island in the Khabur river which currently flows through the city. Zakho has evolved extremely since 1887 . The number of inhabitants is 350 thousand according to directory of statistic in 2012.

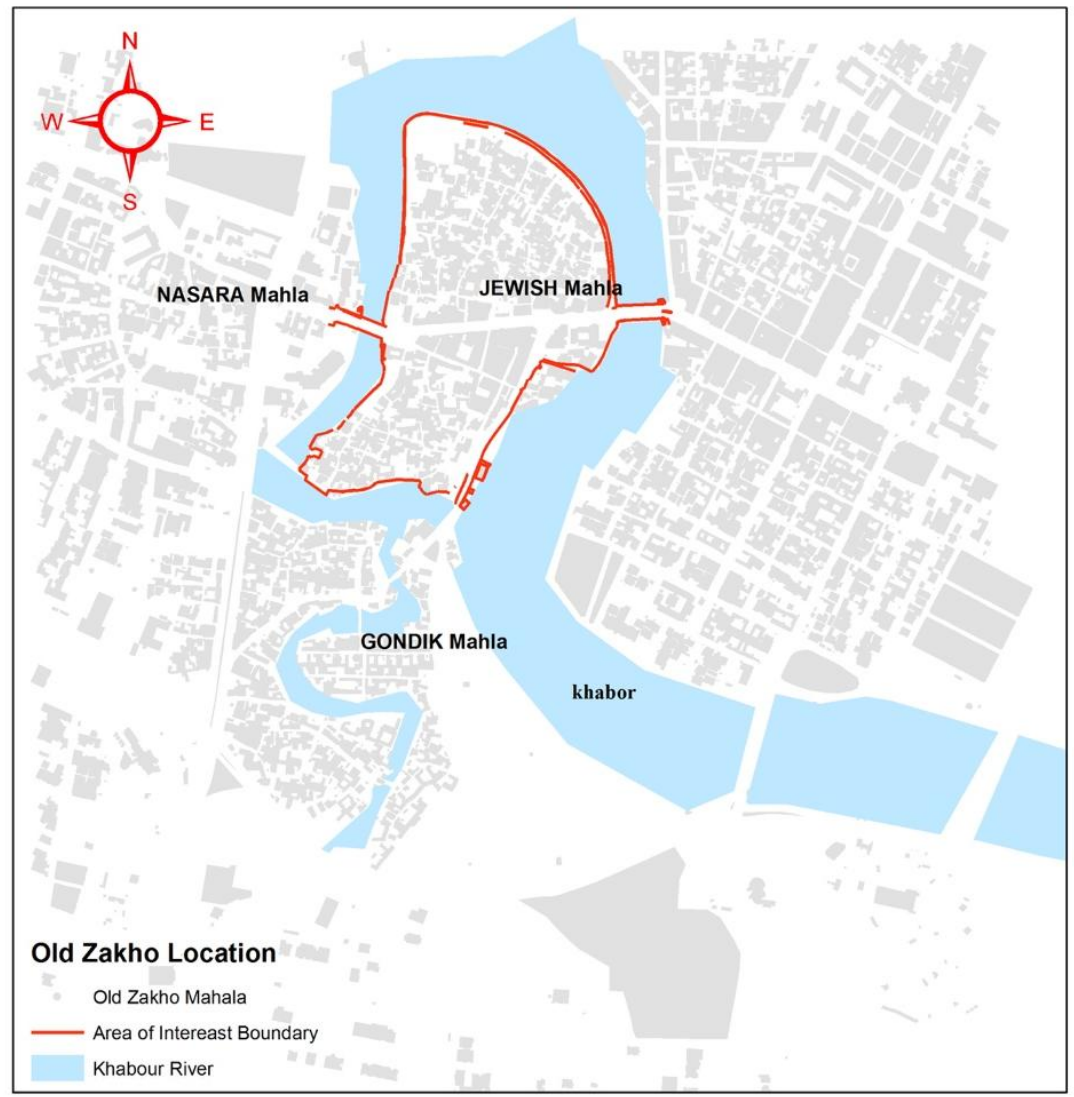

Fig. (1): The old city of Zakho (source: researcher based on zakho master plan report(Duhok Municipalities Directory, 2011)

\section{RESULTS AND DISCUSSION} Urban Morphology of Old Zakho

In general, the old city of Zakho composed of two parts: the historic center and the surrounding residential part. The spatial structure can be seen as organic form. This structure was formed during different historical periods from ancient Assyria, Greek and to Islamic period Figure (2). 

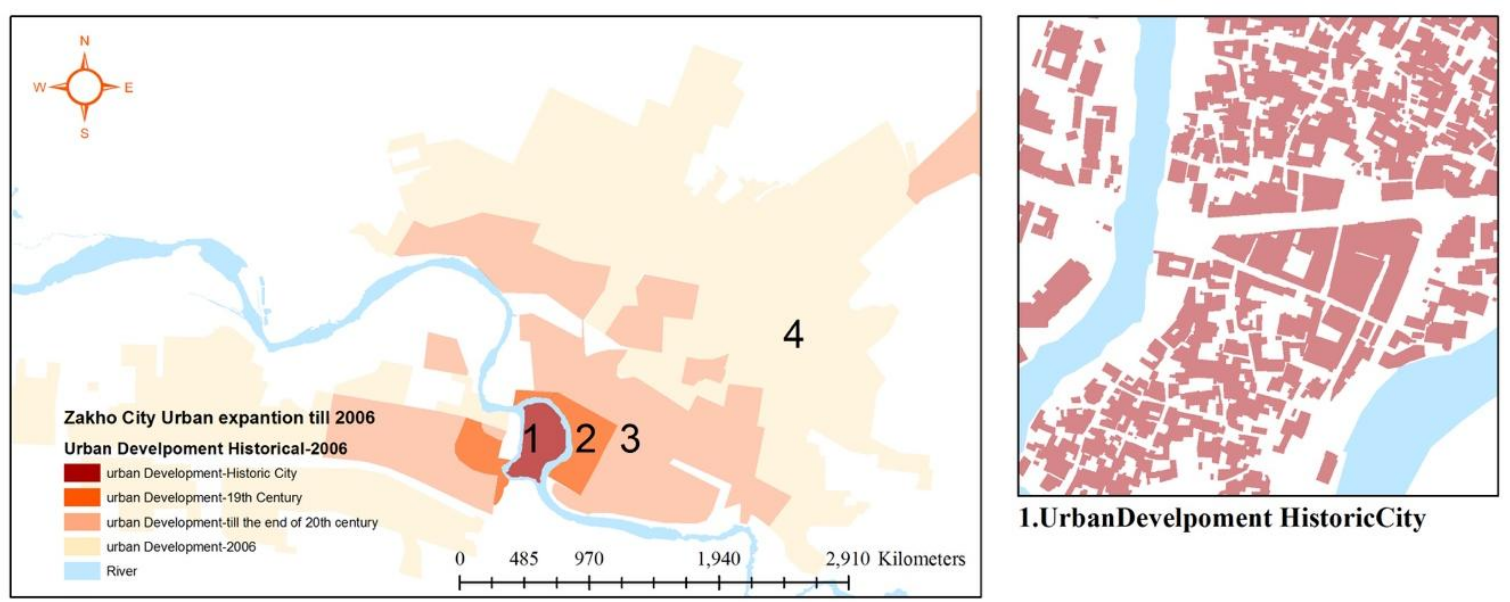

1.UrbanDevelpoment HistoricCity

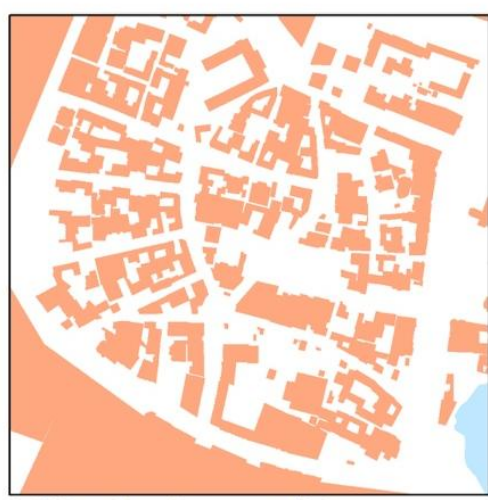

2.Urban Development -19th century

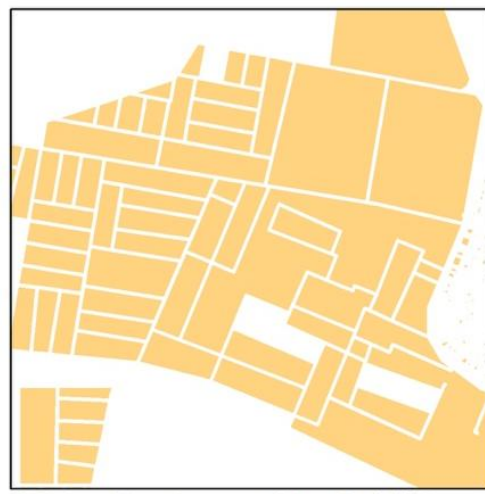

3.Urban Develpment till end of 20th

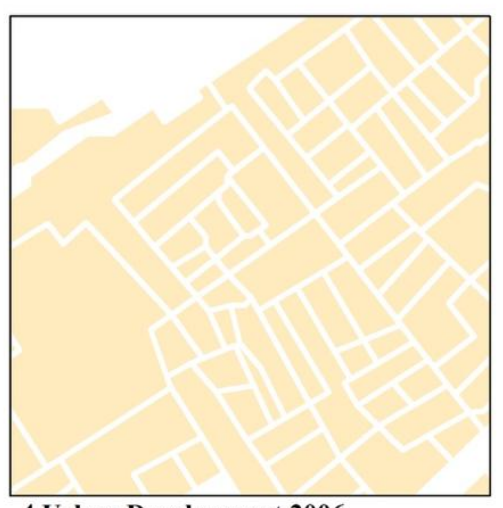

4.Urban Development 2006

Fig. (2): Zakho urban development, visual analysis of urban form for different urban development stages (source: researcher based on zakho master plan report(Duhok Municipalities Directory, 2011)

The green and open spaces are neglected in the city center. The main streets are mostly with dead end and narrow secondary paths to keep the cultural privacy. The components of the city center are the old bazaar (dark bazaar), the main mosque in the center of the bazaar. In addition, there were Khans and orient hamam. (Figure (3))
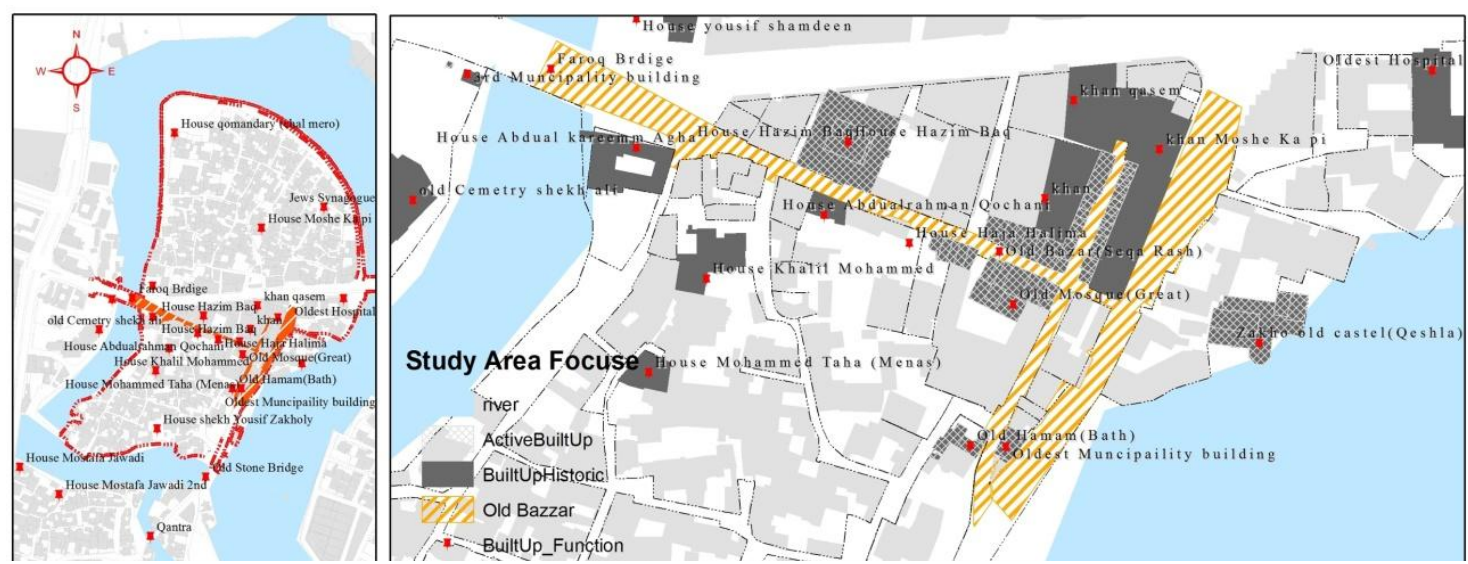

Fig. (3): Zakho old city center, showing the old Bazar street and some old built up area (source: researcher based on Zakho master plan report(Duhok Municipalities Directory, 2011), (سعيد, ץ. 10))

The Bazar ended with the castle "Dar Qishla" Figure $(5,6)$ which is placed at the edge of the
Khabour River. It served as the governor's house in the reign of the Badinan Emirate and was 
extended by Prince Ali Khan. It was built on the ruins of an older castle. It was known to have been built in the 13th century during the Badini Princedom (Duhok Municipalities Directory,
2011). The building fabric of Zakho castle is very damaged and the ensemble has been partly reshaped for new temporary uses.

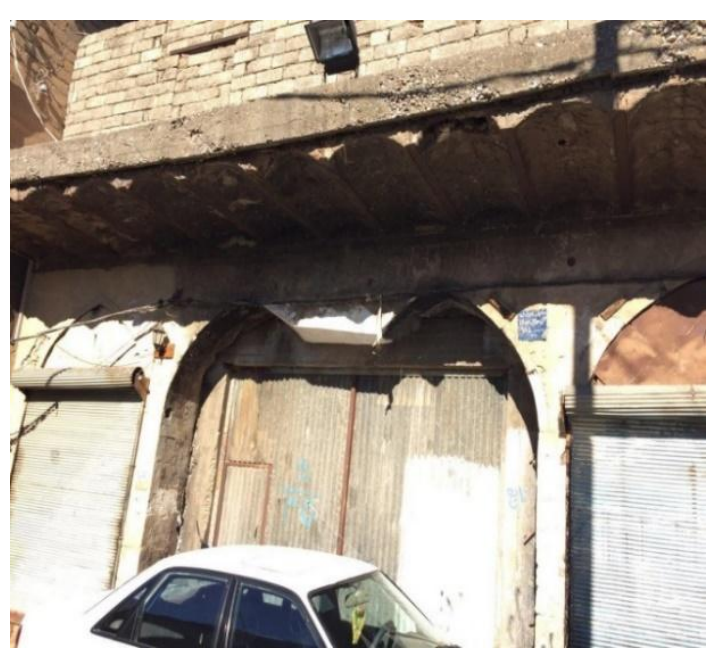

Fig.(4): House in Old bazar street Figure

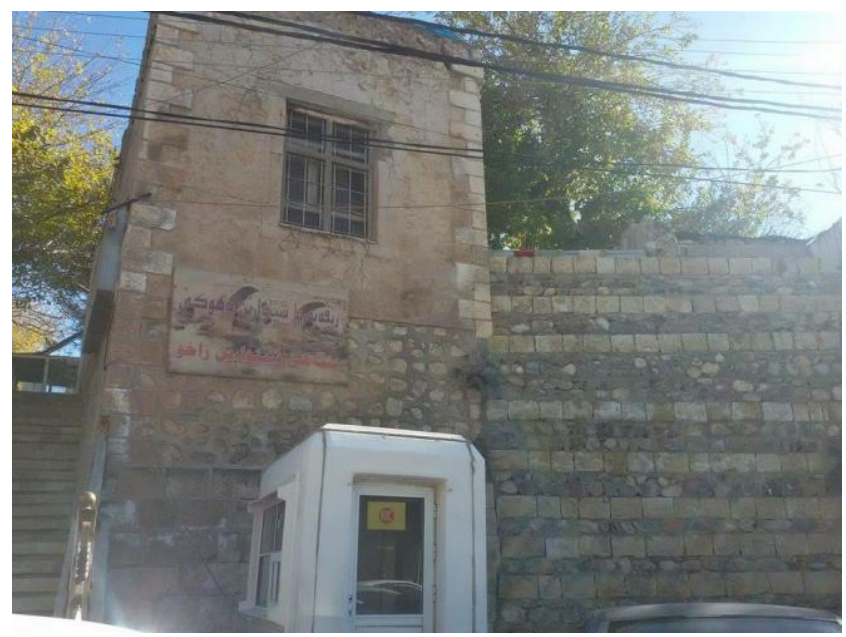

Fig. (5): The Old citadel. (Dar Qishla) source: (Zakho city, Old Zakho Bazar, researcher 2016)

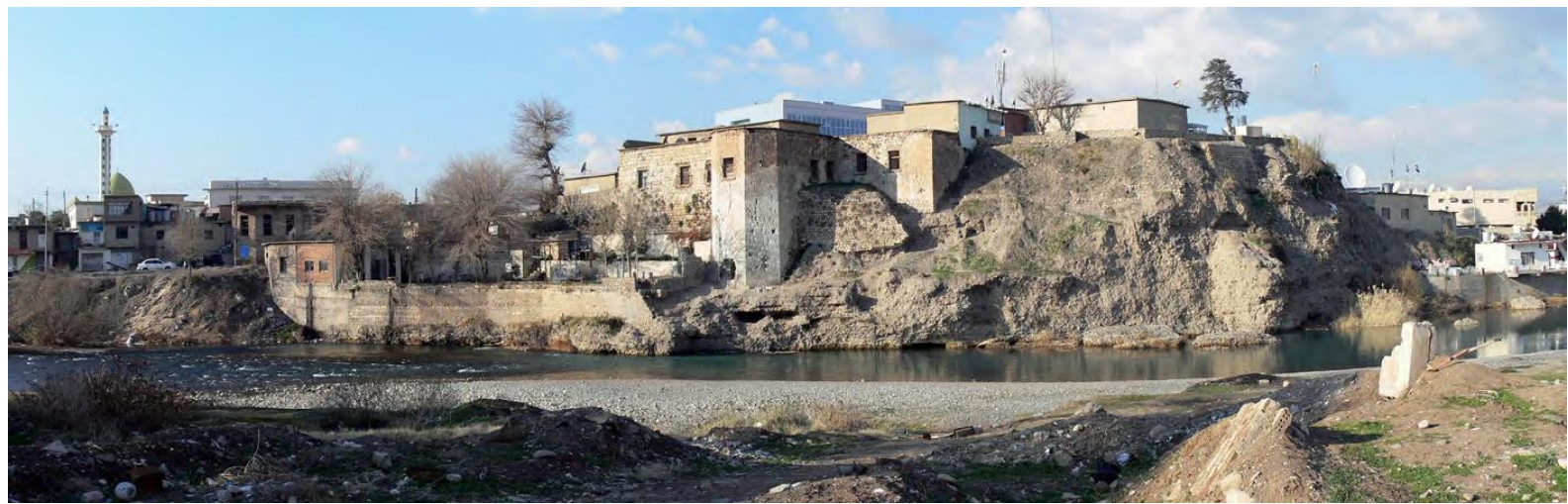

Fig. (6): Zakho Castle today (source: Zakho master plan report (Duhok Municipalities Directory, 2011)
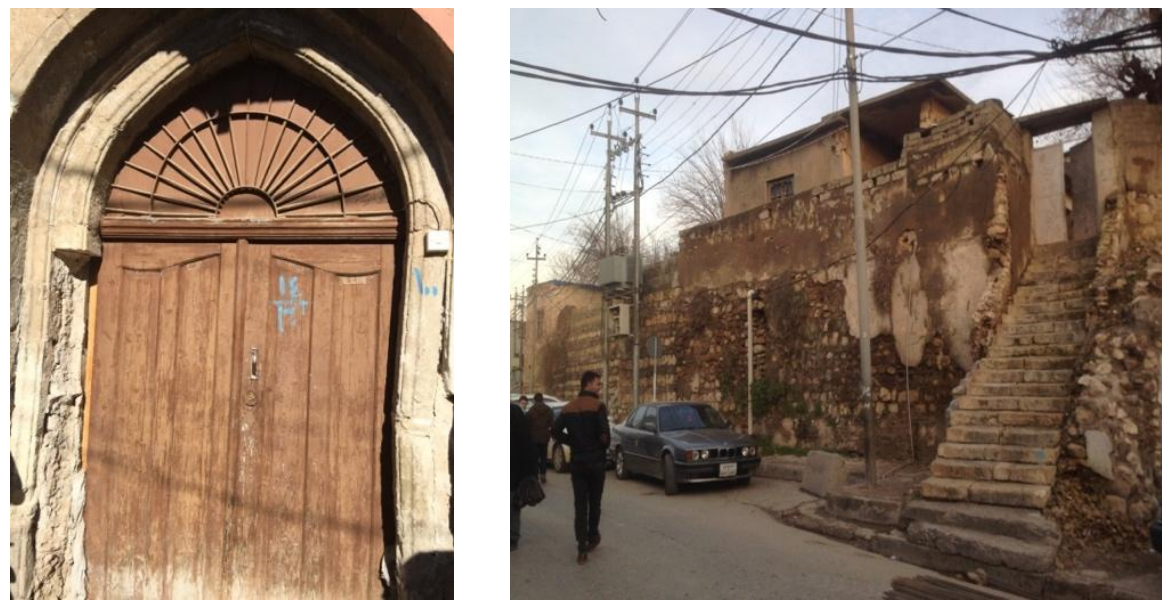

Fig. (7): Architectural style in Zakho old bazar (source: Zakho city, Old Zakho bazar, researcher 2016) 
The problems of the historical area in Zakho

The rapid urban development in Zakho city like all other cities in developing country and the rapid economic transformation change the spatial pattern of land uses. Inner city becomes valuable for commercial land uses. The old tradition buildings decline with its economic, culture and social functions. The main problems of Zakho old city center are

- Lack of maintenance for the old building.

- Lack of public services Figure (8 b,c,e.)
- Lack of access. The city inhabitance, visitor and touristic are not reading and imaging what can be there.

- Disorder of Urban Landscape.

- Lack of green area.

- Lack of awareness among inhabitants about the value of cultural heritage Figure $(8 \mathrm{a}, \mathrm{b})$.

- Poor facilities for tourists and visitor (Attraction points) Figure (8 e).

- Low income people

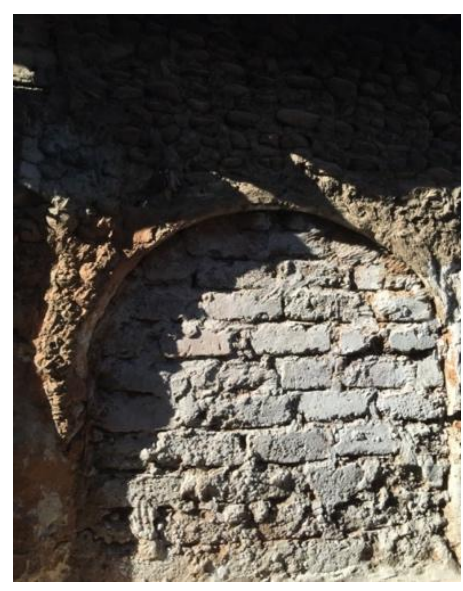

$8 . \mathrm{a}$

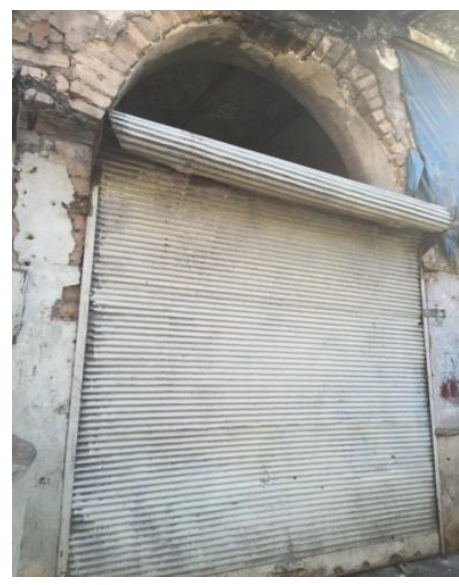

8.d

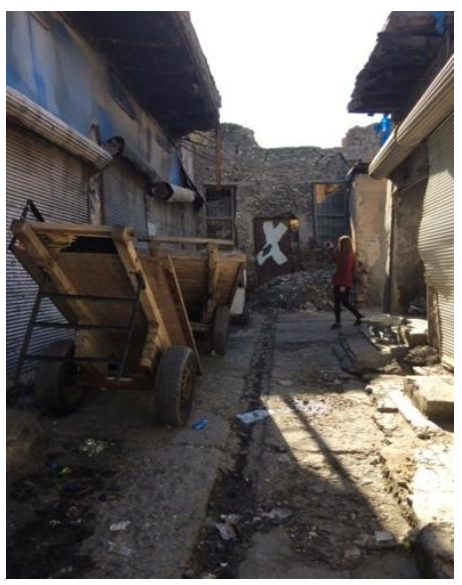

$8 . b$

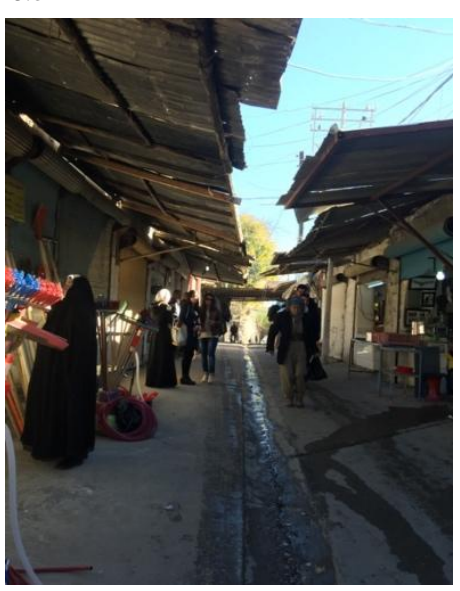

8.e

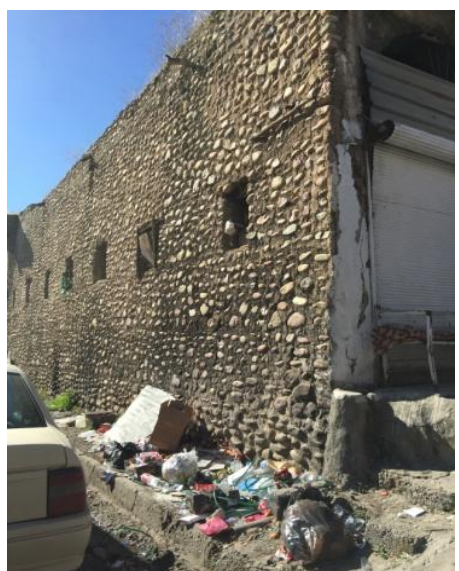

8.c

Fig. (8): Problem of urban decay of old city (source: Zakho city, Old Zakho bazar, researcher 2016)

\section{CONCLUSION}

The regeneration concept defines a new and dynamic approach towards protection and development of historic area. The concept combines between conservation of historic heritage and improving the physical socioeconomic and cultural environment. Based on this approach the regeneration of old city center in Zakho contributes to the protection of the cultural heritage as well as enhancing the local community and inhabitants living environment. The concept can function as a hub for attracting tourism and developing economy.

The research conclude that there is an urgent need to regenerating, maintaining and sustain the 
traditional quality of the historic city area and at the same time adapting the physical structure and the economic activities to the modern present life by adapting new design concepts to enable traditional building to modify the modern needs without destroying the character and value of the urban form. The challenges of regeneration require a new dynamic approach toward preservation and development, an approach that focuses on the protection and conservation of the historical character of the city center with the related socio economic cultural aspects. In this aspect, a clear vision for regenerating the historic area needs to be formulated. The Old center composes some important traditional and cultural heritage, which represent the historic character of the city. To raise the attraction of the old bazaar strategies for promoting the historic character and utilize the center as a space of innovative mix use functions and activities are the main finding of the research. This could be in three levels:

\section{At the Planning Level}

To achieve the regeneration goals and objectives an integrated plan for urban development policy in general that should include urban regeneration is needed. The policy framework should study the issue and problem of urban regeneration including funding, management and operational instruments. The integrated plan comprises interlinked actions to improve the physical, socio economic and environmental condition of the historical area on one hand and the protection of the architectural heritage on the other hand. The development and implementation of action plans needs a sectorial and inter-departmental approach within administrations which involves a wide range of actors from government, civil society and the private sector. Promoting public private partnership in implementing regenerating activities is essential, for example by developing tourists and commercial activity plan. Follow up or evaluation/assessment system plays a big role in a successful regeneration policies or programs to identify the priority and urgency regeneration action plan.

\section{At the urban design level}

The regeneration of old bazar requires introducing new functions to meet the present needs of both inhabitants and visitors. At the same time enhance the attraction of the city center by adding new land use functions, which emphasize the cultural and commercial aspects by developing spaces for cultural activities such as exhibitions, recreation places and tourists facilities services such as hotels and attractive restaurants and leisure activities. Public plaza, green spaces, mobility solution, comfortable pedestrian and greenery will add value to the area and improve the quality of the life in the area. Creating cultural and public activities add value to the city and make it more interesting and unique for the visitors.

\section{At architectural design level}

To enhance the attraction and livability of the old bazar there is a need to introduce new functions for some of the existing buildings or redesign them to accommodate the modern life standards taking into consideration the identity and conservation standards of the historic building and the surrounding urban. The reuse of the existing building should be based on a detailed survey from conservation experts involving academics and university experts to conduct seminars and workshops for the inhabitants and all stakeholders to be part of the decision.

\section{Recommendations and strategies}

The municipality is the key stakeholder in encouraging, facilitating and coordinating development activities in the city. The municipality of Zakho prepared the new master plan of Zakho city as a legal guideline for the city development until 2030. The research recommendation focuses on a new vision for regenerating the old bazaar and city center by creating an attractive center with multiple uses for cultural and tourists' activities, a center that protect the identity of space and its traditional value. The municipality and Zakho local government are asked to consider the following in development plans:

- Conducting a detailed survey for the building condition and listing the heritage building to be preserved and maintained due to conservation standards.

- Infrastructure improvement and maintenance, in order to preserve the physical environment quality of the old center cultural heritage.

- Considering the traditional urban identity in the new development of the building through building regulation law.

- Establishing a heritage fund within the municipality structure for developing and managing the historical heritage 
- Raising public awareness and show the socio economic benefits of the regeneration to improve the living condition in the area.

- Integrating heritage conservation with the provision of open space or parks in the city.

- Establishing public private partnership to encourage investment especially in cultural, tourists and commercial aspects.

- Using participatory planning and stakeholder involvement to decide on conservation aims and action and develop mechanism to arrange various activities

\section{REFERENCES}

- Couch, C. (1990). Urban Renewal: Theory and Practice: Macmillan.

- Duhok Municipalities Directory. (2011). Zakho Master plan Report:Urban Development. Retrieved from

- Holcomb, H. B., \& Beauregard, R. A. (1981). Revitalizing Cities. Resource Publications in Geography: ERIC.

- ICOMOS. (1987). Architectural Heritage Protection Guidelines for Planning Authorities. Retrieved from Washington DC

- Loftman, P., \& Nevin, B. (1995). Prestige projects and urban regeneration in the 1980s and 1990s:
A review of benefits and limitations. Planning Practice \& Research, 10(3-4), 299-316.

- Lorens P. ( 2008). Urban regeneration vs. urban sprawl-problems and prospects in the postsocialistic cities. Paper presented at the SOCARP Congress

- Michailidis T, \& Zaire, D.-T. ( 2011). Historic centers, regenerated urban areas and innovative urban landscapes in Europe: how can they function as a development engine? Paper presented at the 47th ISOCARP Congress Europe.

- Roberts, P., Sykes, H., \& Granger, R. (2000). Urban regeneration. London; Thousand Oaks, Calif.: Sage.

- Smyth, H. (1993). Marketing the City: The role of flagship developments in urban regeneration: Taylor \& Francis.

- Steinberg, F. (1996). Conservation and rehabilitation of urban heritage in developing countries. Habitat International, 20(3), 463-475.

- Temelová, J. (2009). Urban revitalization in central and inner parts of (post-socialist) cities: conditions and consequences.Regenerating Urban Core. . 12-25.

- Zielenbach, S. (2000). The Art of Revitalization: Improving Conditions in Distressed Inner-city Neighborhoods: Garland.

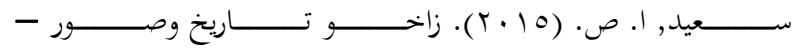

